\title{
Erratum: Numerical simulation of groundwater flowing to horizontal seepage wells under a river
}

\author{
Wei Wang • Ge Zhang
}

\section{Erratum to: Hydrogeology Journal, 15:1211-1220 DOI 10.1007/s10040-007-0171-3}

The authors apologize for some incorrect references.

Please find below the complete, corrected references:

Bear J (1972) Dynamics of fluids in porous media. Elsevier, New York

Beljin MS (1992) A horizontal well model. Ground Water Manage 9:45-54

Chen C (1966) Groundwater hydraulics (in Chinese). Beijing Geology College, China

Chen C (1995) Study of ground water flow model and simulation in three-porosity system of karst channelfracture-porous medium (in Chinese). Earth Sci J China Univ Geosci 20(4):361-366

Chen C, Jiao J (1999) Numerical simulation of pumping test in multilayer wells with non-Darcian flow in the wellbore. Ground Water 37(3):465-474

Chen C, Lin M (1998) Groundwater flow model of mixed well and its application (in Chinese). Publishing House of China University of Geosciences, Wuhan, China

Chen C, Lin M (1999) Groundwater hydraulics (in Chinese). Publishing House of China University of Geosciences, Wuhan, China

Chen C, Jiang J, Lin M (1994) Theory and application of model coupling seepage-pipe flow for unsteady multilayer pumping tests (in Chinese). Science and Technical Report, No. 88172K051, Environmental Geology Institute, China University of Geosciences, Wuhan, China

Published online: 15 January 2008

C) Springer-Verlag 2007

The online version of the original article can be found at http://dx. doi.org/10.1007/s10040-007-0171-3.

W. Wang (®)

School of Environmental Science and Engineering,

Chang'an University,

Xi'an, Shaanxi 710054, People's Republic of China

e-mail: wangwei1@chd.edu.cn

Tel.: +86-298-2339686

Fax: +86-298-2339686

G. Zhang

The 908 Team of Hydrogeology and Engineering Geology,

Lintong, Shaanxi 710600, People's Republic of China
Chen C, Wan J, Zhan H (2003) Theoretical and experimental studies of coupled seepage-pipe flow to a horizontal well. J Hydrol 281(1-2):159-171

Chen T, Zhou Z (1995) Opening up a new water-supply field and construction of a natural filter bed seepage flow well (in Chinese). Prospect Eng (1):11-13

Cheng J, Chen C (1998) Preliminary numerical study of Karst groundwater flow in Beishan area (in Chinese). Hydrogeol Eng Geol (4):50-54

Cleveland TG (1994) Recovery performance for vertical and horizontal wells using semianalytical simulation. Ground Water 32(1):103-107

Fu L, Fang X, Zhang L, Zhang G (2004) Water intake design of seepage wells for a county (in Chinese). Water Waste Water 30 (7):27-30

Hantush MS (1961) Aquifer test on partially penetrating wells. Proc Am Soc Civil Eng 87:171-195

Hantush MS, Papadopulos IS (1962) Flow of groundwater to collector wells. J Hydraul Div ASCE HY25:221-224

Kawecki MW (2000) Transient flow to a horizontal water well. Ground Water 38(6):842-850

Langseth DE, Smyth AH, May J (2004) A method for evaluating horizontal well pumping tests. Ground Water 42(5):689-699

Li W, Xu X (2000) Hydraulics (in Chinese). Publishing House of Wuhan Water Resources and Hydropower University, Wuhan, China

Li X, Yang L (2003) A new water-gathering technique using the infiltration of natural riverbed (in Chinese). China Water Waste Water 19(6):74-76

Tarshish M (1992) Combined mathematical model of flow in an aquifer-horizontal well system. Ground Water 30 (6):931-935

Wang W, Zhang G, Zhao R (2004) Pumpage calculation of seepage well (in Chinese). DIXIASHUI 26(3):41-43

Zhan H, Cao J (2000) Analytical and semi-analytical solutions of horizontal well capture time under no flow and constant head boundaries. Adv Water Resour 23 (8):835-848

Zhan H, Wan J (2003) Horizontal wells in water resources and environmental engineering (in Chinese). Earth Sci J China Univ Geosci 28(5):511-516

Zhan H, Wang LV, Park E (2001) On the horizontal-well pumping tests in anisotropic confined aquifers. J Hydrol 252(1-4):37-50

Zhou W, He W (1997) Analytical solution of unsteady flow in collector well (in Chinese). SHUILI XUBAO (2):79-83 